European journal of American studies

Summer 2015, including Special Issue: (Re)visioning America in the Graphic Novel

\title{
(Re)visioning America in the Graphic Novel: Introduction
}

Michael J. Prince

\section{OpenEdition}

\section{Journals}

Electronic version

URL: https://journals.openedition.org/ejas/10862

DOI: $10.4000 /$ ejas. 10862

ISSN: 1991-9336

Publisher

European Association for American Studies

Electronic reference

Michael J. Prince, "(Re)visioning America in the Graphic Novel: Introduction", European journal of American studies [Online], 10-2 | 2015, document 1, Online since 14 August 2015, connection on 08 July 2021. URL: http://journals.openedition.org/ejas/10862 ; DOI: https://doi.org/10.4000/ejas.10862

This text was automatically generated on 8 July 2021 .

Creative Commons License 


\title{
(Re)visioning America in the Graphic Novel: Introduction
}

\author{
Michael J. Prince
}

1 Comics is an exciting medium which has come into its own both as serious literary and cultural expression, as well as the subject for scholarship. Much of the scholarly discourse of late has been directed at describing and analyzing the medium itself. While comics researchers versed in semiotics and narratology endeavor to construct and refine useful explanatory paradigms, it is also necessary and helpful to employ less medium-specific approaches in discussing and analyzing visual, literary, and societal texts as they are produced. One of the profitable features of the field of American Studies is that it accommodates so many different approaches to read and unpack historical and contemporary events, and the cultural traces they leave; these can be fruitfully detected, elaborated on, and integrated into a variety of theoretical discourses. This special section of the European Journal of American Studies is focused on general and specific elements within American culture in extended comics narratives, portions of series or independent volumes that go under the rubric of the "graphic novel." Nevertheless, "(Re)visioning America in the Graphic Novel" is more for specialists in American Studies than Comics Studies, though these articles treating themes, symbols, and societal and historical considerations, also provide some analysis of generic comics aspects, and they will provide interesting reading for those whose interests are more firmly directed on the medium of comics, or the genre of the graphic novel.

2 While it is not the purpose or intent to here to give an exhaustive definition of the graphic novel, per se, a growing number of scholars provide a basis for doing just that. From a historical perspective, Roger Sabin offers a detailed account of what was originally considered a 
childish form of expression undergoing a gradual renaissance into a full-fledged expressive modality with the deliberate inclusion of mature content from the margins of the "underground comix" scene (7-8). By the early 1980s, comics writers and artists had an outlet for serious, prolonged series that became collected as graphic novels, for instance in the comics magazine 2000AD, and science fiction inspired magazines that were a refreshing alternative from the mainstream (138-139). But, due to the strengths of improved communication with their readers via specialty shop distribution in the United States and the United Kingdom, adult comics became what Sabin terms "the new mainstream" (157), leading to a "'fan comic' style" for series, incorporating "an engaging level of psychological depth" in the characters, and complex plots that demanded consistently keeping up with the new titles as they were released, leading the major comics producers to go for an adult readership (158-160). The year 1986 stands as a watershed in this history of the graphic novel, as Frank Miller's The Dark Night Returns and Alan Moore's Watchmen "received a great deal of critical attention outside fandom, and were even reviewed seriously in broadsheet newspapers" (162). Sabin even goes so far to add that these "titles were repackaged... into square bound books, and then marketed as 'graphic novels'" (165). The operant word here is "marketed," as what we today discuss as the graphic novel has been with us at least since Tintin was put into album form around the middle of the last century. But "by associating them with novels, and disassociating them from comics... [the publishers] hoped that... people would buy them on the grounds that they represented a 'new wave' in literature" (165).

3 From the perspective of students and scholars today, though, this has the ring of some truth in it. Many students of literature and culture read assigned texts on personal digital devices, or even on line, but a graphic novel on the syllabus can reawaken an awareness of the physicality of the book, while at the same time being, if not something other, then at least something more than a book. Some comics artists and critics have convincingly described the difference or added value in a systematic way. This has first and foremost to do with how the "reading" of comics differs from that of prose. In the mid-1980s, Will Eisner discussed this in some depth in his classic Comics and Sequential Art, an instructional guide for those who wanted to draw comics.For the scholar new to comics, and perhaps not yet convinced of its value as a field of study, three additional critical works can be recommended as good places to start.

4 Perhaps the most accessible and arguably the most successful attempt was produced by a comics writer and artist, Scott McCloud. Built on many of the principles outlined by Eisner, his Understanding Comics: The Invisible Art (1994) is among the most cited works on comics. His definition of comics treats the form as juxtaposed sequential art employing at times sparse, iconic representations to draw the reader empathetically into the narrative. The single most engaging feature with McCloud is the fact that his book on comics is 
itself a comic, a fact that has unfortunately given some academics pause. For theoretical perspective, McCloud directly cites Marshall McLuhan and little else. For those that may regard this as a liability, Thierry Groensteen's The System of Comics (published in English in 2007) provides a structuralist poetics of the visual aspects of comics replete with over 200 endnotes, and an analytical vocabulary based upon current semiology. Groensteen enlightens the reading of comics by focusing on the "multiframes" and their influence on each other, what he calls "braiding," within a semiotics of the frame, panel and page, "arthology." Some scholars may find this approach lean on the discussion of narrative, and for them Daniel Steen and Jan-Noël Thon have assembled an anthology with a thorough paradigm constructing introduction, From Comic Strips to Graphic Novels (2013). Stein and Thon's project, realized in their introduction and rehearsed by them and other scholars throughout the book, is to flesh out a "graphic narrative theory" which provides several interstices for the fruition of a historically-minded type of graphic narrative theory. And in this way, Stein and Thon's volume goes deliberately forward to meet the "formal and historical research" of typical comics studies more than half way, providing an effective transmedial narratology that can do for comics analysis what other narratological approaches have done for film.

5 The nine articles in "(Re)visioning America" are, for the most part, more concerned with content than the more esoteric elements of the formal aspects of comics. Yet they do make important contributions to comics scholarship by also bringing on board theoretical perspectives which are useful to illuminate any text from an American Studies perspective.

6 The first two articles approach the issue of what may be roughly termed "ethnic-based comics" through in-depth discussions with the producers of comics the author / artists themselves, highlighting the importance of space, the body, and language in a society that has imperfectly handled the diversity of native and immigrant minorities. Kristina Aurylaite has conversed extensively with Dakota-Anishinabe Brian Wright-McLeod as an integral part of her analysis of his graphic novel Red Power and the strategies he employs visually and textually to portray Native-American identity. Aurylaite's careful use of post-colonial theories of space, and several insightful examples of the comics form, both by her and Brian Wright-McCloud, argue conclusively that WrightMcCloud's graphic novel Red Power "exposes the same logic behind colonial ways of looking at and conceiving indigenous space and bodies, projecting the same logic of assessment and categorization onto both, which leads to the practices of exclusion and restriction to shrink and reduce (the possibilities of) them both."

7 Jaime Cleland's interview with Leela Corman about her graphic novel Untersakhn explores the transplanted European heritage of Azkhenazi Jews in New York, and the identities that unfurl historically in the new generations, and among women, pursuing how the "family 
dynamics" of an lower East Side Jewish family in the early decades of the twentieth century develop, and illuminating "class and gender concerns across time and space." Unlike Wright-McCloud, who leaves settings and particular historical situations deliberately vague, Leela Corman elaborates on the amount of research and detail work she puts into her literary graphic novels. Early in Cleland's interview, Corman and her interviewer speak of the coterie of Jewish comics writers, and whether she considers herself a member.

8 The third article-the first of three to discuss mainstream superhero comics-in part problematizes that category, particularly when it comes to ethnic identity assumption of highly stylized fantastic characters. Martin Lund's "The Mutant Problem: X-Men, Confirmation Bias, and the Methodology of Comics and Identity" broadly discusses concerns of the Cold War, Civil Rights, and especially Jewish identity within several authors and characters of this series. Lund demonstrates how the generically endorses extreme historical episodes, such as intolerance, atrocities and war, lend themselves to simplification and utilization as characterizing devices within a narrative series. He cautions against a tendency to simplify identities and link comics characters to a single offending or victimized ethnic group. While implying that such simplifications may do disservice to one or more minorities, such an approach cannot but help to skew the reading of superhero comics genre. "The common notion that 'everybody knows that'... [a] character 'is' one thing or another overlooks the constancy of changes and ruptures in continuity that often radically redefine it."

9 In "The Dark Knight's Dystopian Vision: Batman, Risk, and American National Identity," Jeanne Cortiel and Laura Oehme sharpen the focus on a relatively recent historical shift during the period between Chernobyl and 9/11 that marks a crisis in American identity, drifting away from the more optimistic, progressive elements to those that feature "a specific type of anticipatory consciousness" they "read as risk consciousness." Frank Miller's The Dark Knight Returns and The Dark Knight Strikes Again are read against the grain to highlight a dystopian turn in American identity, showing that Miller's depiction of space transfers the locus of responsive agency from the exemplar metropolis to the planet as a whole. This broader field of action, and a mediascape, in typical Frank Miller fashion, satirized by highlighting the cognitive dissonance of the "non-knowledge society," are linked to a crisis in typically American notions of masculinity. The Dark Knight books, then, "envision a dystopian future threatened by anthropogenic apocalypse and characterized by non-knowing and indecision."

10 Maaheen Ahmed also treats post 9/11 tensions within America; in "State protection and identification in Hellboy: of reformed devils and other Others in the Pentagon," she discusses notions of individual and collective American identity in the figure Hellboy, and the eponymous series. In particular, Ahmed highlights Hellboy's monstrous (i.e. nonhuman) identity as problematical both in the typically American notions 
of individual, immigrant, and as his role for the Pentagon as both being and combatting the demonic. The article branches into generic concerns, as well, revealing a decided shift to fantasy in the series after 9/11, and exploring how Hellboy plays with and off of the mandates to the Comics Code Authority.

11 The next two articles are regionally specific, dealing with social and economic perceptions and realities in the northwest and southeast of the United States. In "The Monsters of Suburbia: Black Hole and the mystique of the Pacific Northwest," Fiorenzo Iuliano argues that Charles Burns' 12-part series from the 1990s interrogates the mythologized Pacific Northwest as an ecological oasis. Nature in this graphic novel, argues Iuliano, is portrayed "as a cultural artifact that... has been... used to disguise those processes of urban expansion that have determined the social marginalization of specific categories of people." By invoking other texts, and Seattle's reputation as the cauldron for Generation X, this article shows that what can be at first blush understood as "nature" is cleverly enclosed within the sprawling urban metropolis.

12 In “Rudy Kelly's Eyes: Chris Hedges and Joe Sacco's Days of Destruction, Days of Revolt," Øyvind Vågnes analyzes strategies of visual representation within a prose-comics documentary work. While undeniably stretching the consideration of graphic narratives, "imagetexts" such as these are more than mere continuations of the tradition of photographic indexicality; the comics quality in their physical articulation of the subjects, such as Rudy Kelly, "defines the book's commitment to their stories." Joe Sacco's numerous other works derive a similar authenticity in this approach, the hand-drawn journalism of the graphic documentary.

13 The last two articles approach the graphic novels from a cultural mythology "Americanist" approach, mapping American utopianism and the mythology of the American West into their respective texts. Matt Yockey's "Ti-Girl Power: American utopianism in the Queer Superhero Text" shows how Jaime Hernandez's graphic novel God and Science: Return of the Ti-Girls undermines the broad Anglo-American master narratives which support the myths of progress endorsed by the Silver Age superhero comics. Hernandez's strategies in this project include illustrating the multiple production of subjectivity in children, women, and intertextual allusions to mainstream comics to create a multifaceted American identity that depends upon "the difference one pines for," and thereby transform "the... boundaries of individual and national identities."

14 In "Skinner Sweet, American Vampire," James J. Donahue convincingly illustrates how the figures of Skinner Sweet, Pearl and Travis Kidd in the first four volumes of Scott Snyder and Rafael Albuquerque's American Vampire exemplify and play off of the presuppositions of the signature myth of American exceptionalism, the myth of the American West. Sweet combines the born-of-the-earth 
savagery of the Indian with the can-do of the frontiersman, becoming "an undead embodiment of American cultural change" until his central positive role is replaced by rock-n-roller Travis Kidd later in the series. This re-use of the myths are linked with "paradigmatic moments of American history [that] have been used to justify American exceptionalism." And with this, "(Re)visioning America" comes full circle, examining a series that responds to, and occasionally uncritically endorses, the very ideology used to remove natives from their lands as shown in Brian Wright-McCloud's Red Power.

15 American Studies is, as all vital and creative fields in scholarship, in a state of constant transition. By bringing the medium of comics into the mix of cultural analysis, a richer weave in the tapestry of inquiry may encourage students to become better acquainted with a popular multimodal genre, one that is enjoying increasing attention from readers and scholars. It is still the case that comics does not enjoy complete cultural legitimacy, either as a visual art-form, nor as literature. But they are getting closer.

\section{BIBLIOGRAPHY}

Eisner, Will. Comics and Sequential Art: Principles and Practices from the Legendary Cartoonist. London: Norton, 2008. Print.

Groensteen, Thierry. The System of Comics. Trans. Bart Beaty and Nick Nguyen. Jackson: University Press of Mississippi, 2007. Print.

McCloud, Scott. Understanding Comics: The Invisible Art. New York: Harper Collins, 1994. Print. Sabin, Roger. Comics, Comix \& Graphic Novels: A History of Comic Art. London: Phaidon, 1996. Print. Stein, Daniel, and Jan-Noël Thon, eds. From Comic Strips to Graphic Novels: Contributions to the Theory and History of Graphic Narrative. Berlin: De Gruyter, 2013. Print.

\section{AUTHOR}

MICHAEL J. PRINCE

University of Agder 